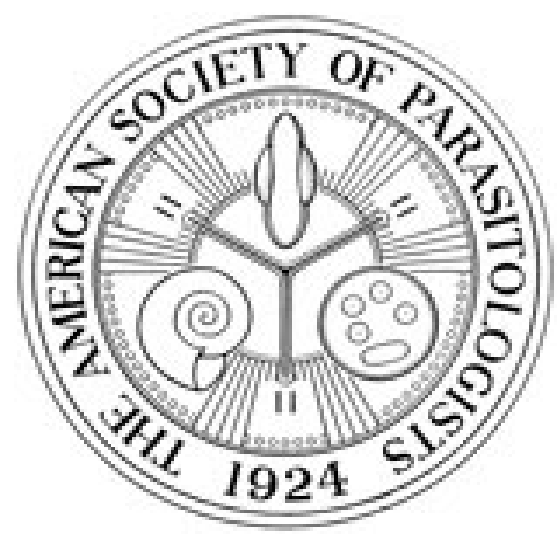

Complete Development of the Porcine Coccidium Isospora suis Biester, 1934 in Cell Cultures Author(s): David S. Lindsay, Doug P. Quick, Ann M. Steger, Maria A. Toivio-Kinnucan and Byron L. Blagburn

Source: The Journal of Parasitology, Vol. 84, No. 3 (Jun., 1998), pp. 635-637

Published by: The American Society of Parasitologists

Stable URL: http://www.jstor.org/stable/3284741

Accessed: 19/06/2014 10:36

Your use of the JSTOR archive indicates your acceptance of the Terms \& Conditions of Use, available at http://www.jstor.org/page/info/about/policies/terms.jsp

JSTOR is a not-for-profit service that helps scholars, researchers, and students discover, use, and build upon a wide range of content in a trusted digital archive. We use information technology and tools to increase productivity and facilitate new forms of scholarship. For more information about JSTOR, please contact support@jstor.org.

The American Society of Parasitologists is collaborating with JSTOR to digitize, preserve and extend access to The Journal of Parasitology. 
1997. Reversal of P-glycoprotein-associated multidrug resistance by ivermectin. Biochemical Pharmacology 53: 17-25.

Precious, W. Y., AND J. BARRETT. 1989. Xenobiotic metabolism in helminths. Parasitology Today 34: 27-31.

RafFA, K. F., AND T. M. PRIESTER. 1985. Synergists as research tools and control agents in agriculture. Journal of Economic Entomology 2: $27-45$.

RieHM, H., AND J. L. BIEDLER. 1972. Potentiation of drug effect by
Tween 80 in Chinese hamster cells resistant to actinomycin D and daunomycin. Cancer Research 32: 1195-2000.

SANGSTER, N. C. 1994. P-glycoproteins in nematodes. Parasitology Today 10: $319-322$.

1996. Pharmacology of anthelmintic resistance. Parasitology 113(suppl.): S201-S216.

TEsta, B., AND P. JenNer. 1981. Inhibitors of cytochrome P-450s and their mechanism of action. Drug Metabolism Reviews 12: 1-117.

\section{Complete Development of the Porcine Coccidium Isospora suis Biester, 1934 in Cell Cultures}

David S. Lindsay, Doug P. Quick*, Ann M. Stegert, Maria A. Toivio-Kinnucan $\ddagger$, and Byron L. Blagburn $\ddagger$, Center for Molecular Medicine and Infectious Diseases, Department of Biomedical Sciences and Pathobiology, Virginia-Maryland Regional College of Veterinary Medicine, Virginia Tech, 1410 Prices Fork Road, Blacksburg, Virginia 24061-0342; *3708 Skyline Circle, Des Moines, lowa 50310; †Ambico, Inc., 902 Sugar Grove Avenue, Dallas Center, lowa 50063; and ‡Department of Pathobiology, College of Veterinary Medicine, Auburn University, Alabama 36849-5519

ABSTRACT: Development from inoculated sporozoites to unsporulated oocysts of Isospora suis Biester, 1934 is described in a swine testicular (ST) cell line. Sporozoites penetrated ST cells within $1 \mathrm{hr}$ postinoculation (PI). Development was initially by endodyogeny to produce binucleate type I meronts and type I merozoites. Division by endodyogeny continued during the 13-day observation period and type I merozoites were the developmental stages most abundant at observation periods $>3$ days PI. Mutinucleate type II meronts and type II merozoites were first observed 7 days PI. Gamonts and oocysts were present 12 days PI. Oocysts did not sporulate in vitro. The ultrastructural features of stages were similar to those that occur in the pig host.

Isospora suis Biester, 1934 is the causative agent of neonatal porcine coccidiosis. This disease causes morbidity and mortality in nursing pigs and is a common production problem in the swine industry in the United States and other countries worldwide (see Lindsay et al., 1997).

Fayer et al. (1984) were the first to describe development of I. suis in cell cultures. Development was limited to replication by endodyogeny. Lindsay and Blagburn (1987) reported similar findings in primary porcine and bovine kidney cell cultures; however, they did observe a few multinucleate stages that resembled type II meronts (Lindsay et al., 1980) of I. suis. The present study reports complete development of $I$. suis from sporozoites to unsporulated oocysts in a swine testicle cell line.

Infection and fixation of cell cultures were conducted at Ambico, Inc., Dallas Center, Iowa. Processing of tissues for transmission electron microscopy (TEM) and TEM observations were done in the Department of Pathobiology, College of Veterinary Medicine, Auburn University, Alabama. Examination of thin sections and electron micrographs were conducted in the Center for Molecular Medicine and Infectious Diseases, Department of Biomedical Sciences and Pathobiology, VirginiaMaryland Regional College of Veterinary Medicine, Virginia Tech, Blacksburg, Virginia.

A diploid swine testicle (ST) cell line (Ambico, Inc., Dallas Center, Iowa) was used. The ST cells were grown in minimum essential medium with Earle's salts supplemented with $10 \%$ (v/ v) bovine calf serum and $100 \mu \mathrm{g} / \mathrm{ml}$ gentamicin. Cells were plated at $1.25 \times 10^{6} \mathrm{ST}$ cells per $25-\mathrm{cm}^{2}$ cell culture flask.
Cultures were incubated at $37 \mathrm{C}$ in an incubator with a $5 \%$ $\mathrm{CO}_{2}-95 \%$ air atmosphere.

Sporozoites of $I$. suis were obtained from sporulated oocysts and separated from oocyst/sporocyst walls as previously described (Lindsay et al., 1983; Lindsay and Current, 1984). Between 1.25 and $5 \times 10^{5}$ sporozoites in $5 \mathrm{ml}$ of inoculation medium were used for infection of ST cell cultures. The inoculation medium consisted of Dulbecco's modified Eagle's medium (DMEM) supplemented with $10 \%$ bovine calf serum, 0.1 M HEPES buffer, and $100 \mu \mathrm{g} / \mathrm{ml}$ gentamicin. Sporozoites were allowed $75 \mathrm{~min}$ to penetrate ST cells, then any extracellular sporozoites were removed by washing the monolayer 3 times with DMEM. Ten milliliters of the DMEM was then added to the monolayer and they were incubated at $37 \mathrm{C}$ until processed for TEM.

Flasks of infected ST cells were processed for TEM 1 and $22 \mathrm{hr}$ and $3,4,5,7,10,12$, and 13 days postinoculation (PI). The ST cells were scraped from the plastic growth surface using a cell scraper and pelleted by centrifugation. The cell pellet was fixed in 3\% (v/v) glutaraldehyde in Millonig's phosphate buffer (pH 7.4). The pellets were postfixed in $1 \%(\mathrm{w} / \mathrm{v})$ osmium tetroxide, dehydrated in a series of ethanols, passed through 2 changes of propylene oxide, and embedded in Spurr resin (Polysciences Inc., Warrington, Pennsylvania). Thin sections were stained with uranyl acetate and lead citrate and examined with a Philips 301 transmission electron microscope operating at $60 \mathrm{kV}$. Additionally, $1-\mu \mathrm{m}$-thick sections were placed on glass microscope slides and stained with toluidine blue and examined by light microscopy.

Sporozoites were the only stages observed 1 and $22 \mathrm{hr}$ PI. Division by endodyogeny had occurred by 3 days PI and ST cells with up to 8 type I merozoites were present. Infected ST cells containing type I merozoites were observed at every observation period from days 3 to 13 PI when the last sample was examined and they were always the most abundant stage present. The length of time sporozoites remained could not be determined because sporozoites closely resemble type I merozoites. Type II meronts and type II merozoites were first observed 


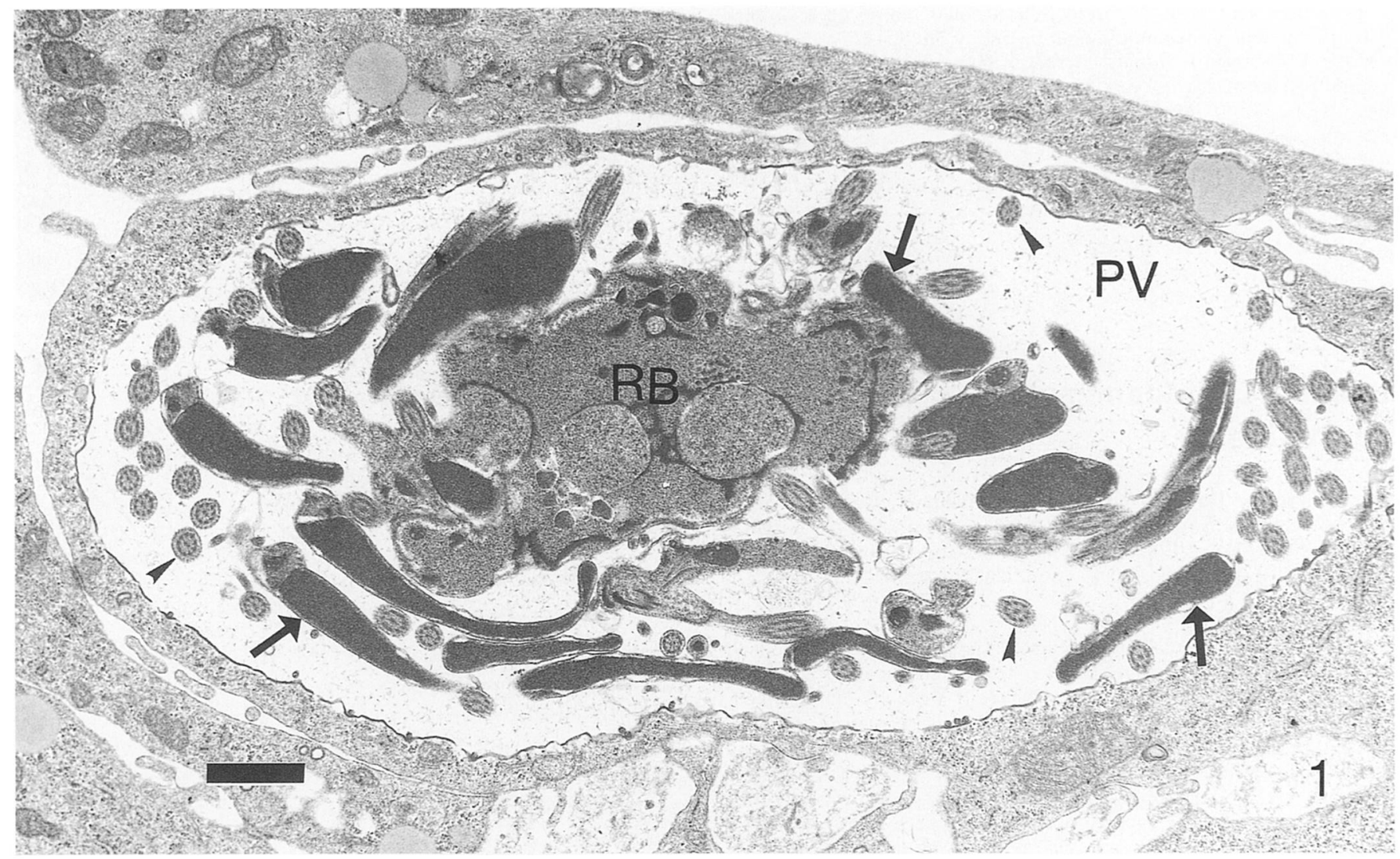

FIGURE 1. Transmission electron micrograph of a microgamont of Isospora suis in a swine testicular cell. The microgamont is in a parasitophorous vacuole (PV). Note nuclei (arrows) and flagella (arrowheads) of the microgametes that are arising from a residual body $(\mathrm{RB})$. Bar $=1 \mu \mathrm{m}$.

day 7 PI. Sexual stages and oocysts were first seen 12 days PI (Figs. 1, 2). Host cells containing asexual and sexual stages in the same cells were occasionally observed. Oocysts did not sporulate in vitro. No attempts were made to induce sporulation of in vitro-produced oocysts. Continuous culture of $I$. suis was not achieved.

The ultrastructural features of the endogenous stages of $I$. suis in ST cells are similar to those described in experimentally infected pigs (Matuschka and Heydorn, 1980; Matuschka, 1982), for sporozoites and type I meronts and merozoites of $I$. suis in cell cultures (Lindsay et al., 1991), and in vitro-excysted I. suis sporozoites (Pinckney et al., 1993). The timing of appearance of type II meronts and merozoites and sexual stages was delayed in vitro over that observed in pigs (Lindsay et al., 1980; Matuschka and Heydorn, 1980).

Lindsay and Current (1984) obtained complete development of $I$. suis in the chorioalantoic membrane of chicken embryos. However, previous attempts to obtain complete development of mammalian Isospora species in cell cultures have been unsuccessful (Fayer, 1972; Fayer and Mahrt, 1972; Fayer and Thompson, 1974; Fayer et al., 1984; Lindsay and Blagburn, 1987). The vast majority of Eimeria species examined in vitro complete only 1 or 2 asexual generations.

Many factors influence development of coccidian parasites in vitro (see Strout and Schmatz, 1990; Upton, 1997), and it is often difficult or seemingly impossible to find the precise conditions needed for a particular species. Eimeria tenella, Cryptosporidium parvum, Caryospora simplex, and Caryospora bi- genetica can be grown from sporozoites to unsporulated/sporulated oocysts in cell cultures (Upton et al., 1984; Sundermann et al., 1988; Strout and Schmatz, 1990; Upton, 1997). In vitro culture systems offer an excellent system for examining many aspects of coccidial biology and will be essential in identifying factors involved in developmental stage conversion and induction of the sexual cycle in coccidian parasites.

\section{LITERATURE CITED}

FAYER, R. 1972. Cultivation of feline Isospora rivolta in mammalian cells. Journal of Parasitology 58: 1207-1208.

- H. R. Gamble, AND J. V. ERnST. 1984. Isospora suis: Development in cultured cells with some cytological observations. Proceedings of the Helminthological Society of Washington 51: 154159.

, AND J. L MAHRT. 1972. Development of Isospora canis (Protozoa: Sporozoa) in cell cultures. Zeitschrift für Parasitenkunde 38: 313-318.

- AND D. E. ThOMPSON. 1974. Isospora felis: Development in cultured cells with some cytological observations. Journal of Parasitology 60: 160-168.

Lindsay, D. S., AND B. L. Blagburn. 1987. Development of Isospora suis from pigs in primary porcine and bovine cell cultures. Veterinary Parasitology 24: 301-304.

- AND W. L. CURRENT. 1984. Complete development of Isospora suis of swine in chicken embryos. Journal of Protozoology 31: $152-155$.

- AND J. V. ERNST. 1983. Excystation of Isospora suis Biester 1934 of swine. Zeitschrift für Parasitenkunde 69: 27-34.

, AND M. A. ToIvIO-KInNUCAN. 1991. Ultrastructure of developing Isospora suis in cultured cells. American Journal of Veterinary Research 52: 471-473. 


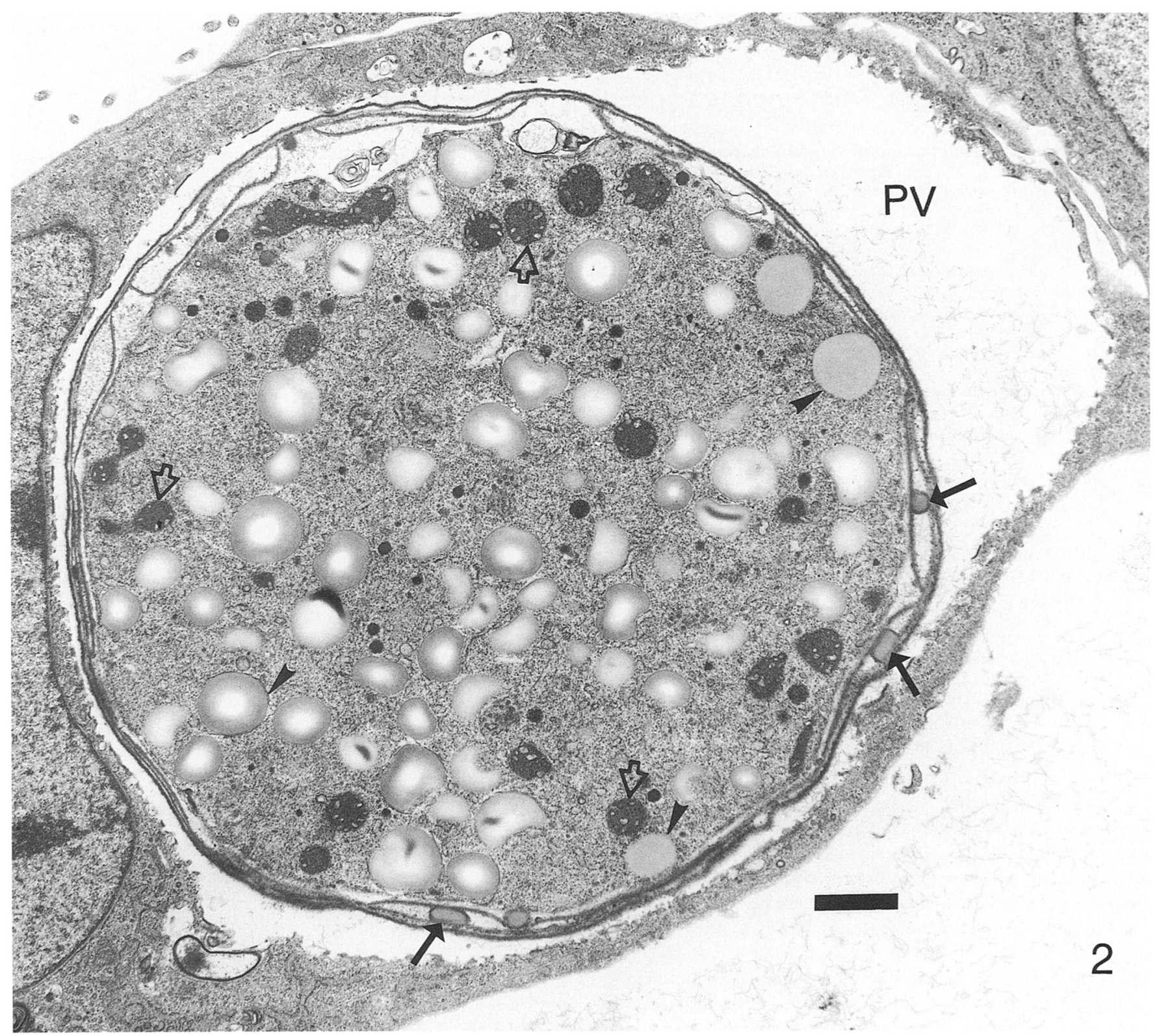

FiguRE 2. Transmission electron micrograph of a developing oocyst of Isospora suis in a swine testicular cell. The oocyst is in a parasitophorous vacuole (PV). Note the wall-forming bodies type I (arrowheads) and wall-forming bodies type II (open arrows). Some of the wall-forming bodies type I (arrows) have been exocytosed and are between membranes in the developing oocyst wall. Bar $=1 \mu \mathrm{m}$

J. P. Dubey, and B. L. Blagburn. 1997. Biology of Isospora spp. from humans, nonhuman primates, and domestic animals. Clinical Microbiology Reviews 10: 19-34.

- , B. P. Stuart, B. E. Wheat, And J. V. Ernst. 1980. Endogenous development of the swine coccidium, Isospora suis Biester 1934. Journal of Parasitology 66: 771-779.

MatuschKA, F. R. 1982. Ultrastructural evidence of endodyogeny in Isospora suis from pigs. Zeitschrift für Parasitenkunde 67: 27-30.

, AND A. O. HeYdoRn. 1980. Die Entwicklung von Isospora suis Biester und Murray 1934 (Sporozoa: Coccidia: Eimeriidae) im Schwein. Zoologische Beiträge 26: 405-476.

Pinckney, R. D., D. S. Lindsay, M. A. Tolvio-Kinnucan, and B. L. BLAGBURN. 1993. Ultrastructure of Isospora suis during excystation and attempts to demonstrate extraintestinal stages in mice. Veterinary Parasitology 47: 225-233.
Strout, R. G., And D. M. Schmatz. 1990. Recent advances in the in vitro cultivation of the coccidia. In Coccidiosis of man and domestic animals, P. L. Long (ed.). CRC Press, Inc., Boca Raton, Florida, p. 221-233.

Sundermann, C. A., D. S. Lindsay, R. E. Tibbs, and M. A. Bailey. 1988. Complete development of Caryospora bigenetica (Apicomplexa: Eimeriidae) in vitro. Journal of Protozoology 35: 465-469.

Upton, S. J. 1997. In vitro cultivation. In Cryptosporidium and cryptosporidiosis, R. Fayer (ed.). CRC Press, Boca Raton, Florida, p. 181-207.

, T. B. Haynes, W. L. Current, and S. M. Barnard. 1984. Development of Caryospora simplex (Apicomplexa: Eimeriidae) from sporozoites to oocysts in human embryonic lung cell culture. Journal of Protozoology 31: 398-402. 